\title{
4. 高度BSデジタル放送
}

\section{4-1. 高度BSデミ゙タル放送技術}

(正会員) 橋 本 明 $\bar{z}^{\dagger}$, (正会員) 田中祥 次 ${ }^{\dagger}$

キーワードロ 衛星デジタル放送, ISDB-S, LDPC, APSK, バルク伝送, UHDTV

\section{1ま え がき}

高度BSデジタル放送は，2011年以降にアナログ放送終了 後の3チャネルと世界無線会議 (WRC2000) で割当てられた 4 チャネルの計7チャネルでの利用を目指し, 現在, 電波産 業会 (ARIB) で規格化が進められている放送方式である. 本方式の特長として, 現行のBSデジタル放送規格ISDB-S (Integrated Services Digital Broadcasting-Satellite)に比 べて $30 \%$ 以上の伝送容量拡大を可能としたことや, 映像符 号化にハイビジョンを超える映像フォーマットを取り入れ ていることなどが挙げられ, 将来的にはスーパーハイビジ ヨン伝送にも対応可能となっている.

本稿では, 衛星放送高度化の動向と高度BSデジタル放送 の技術仕様について解説する.

\section{2 衛星デジタル放送高度化の動向}

\section{1 狭帯域CSデジタル放送}

狭帯域CSデジタル放送は1995年，東経128のCSを使い， DVB-S方式を採用して開始された。近年, 欧州の衛星放送 規格DVB-S2や中国の地上デジタル放送方式DMB-T, 無線 通信方式IEEE802.16eでLDPC (Low Density Parity Check) 符号が採用されるなど，LDPC符号の実用化が進むなか, 2006年7月に, 伝送路符号化にDVB-S2方式 (8PSK+LDPC $(r=2 / 3,3 / 5))$, 多重化にMPEG-2 Systems, また, 映像 符号化にH.264/MPEG-4 AVCを用いることが適当とする情 報通信審議会 (以後, 情通審) の答申が出された. この方式 を用いたHDTV放送は，2008年秋を目処に開始される予定 である。

\subsection{BSデジタル放送および広帯域CSデジタル放送}

BSデジタル放送については, 2006年9月, 総務省から情 通審に, 諮問2023号「放送システムに関する技術的条件」が 出され, その中で,「衛星デジタル放送の高度化に関する 技術的条件」が求められており，2007年3月の情通審で，今

\section{$\dagger$ NHK 放送技術研究所}

"Advanced Satellite Digital Broadcasting; Advanced Satellite Digital Broadcasting Technology" by Akinori Hashimoto and Shoji Tanaka (Science \& Technical Research Laboratories, NHK, Tokyo)
後利用可能となるBS周波数における放送方式の技術的条件 についての検討をARIBに依頼する方針が示され，4月より， ARIBのデジタル放送システム開発部会で新方式の検討が 進められている。なお, 今回の高度化は, 広帯域CSデジ夕 ル放送も対象としている.

\section{3 高度BSデジタル放送の暫定方式案の概要}

ARIBは放送方式の募集を行い，提案された伝送路符号 化方式, 映像符号化方式, 音声符号化方式, デー夕符号化 方式, 多重化方式の各分野について審議を進めており, 2008年1月には情通審に，中間報告として暫定方式案を報 告している. 暫定方式案の概要を表1〜表5にまとめる.

\section{1 伝送路符号化方式}

(1) 特 長

$\mathrm{LDPC}$ 符号の採用による所要 $\mathrm{C} / \mathrm{N}$ 低減とロールオフ率 0.1 の採用によるシンボルレートの拡大により, 8PSK (符号化 率3/4）を利用した場合で, ISDB-Sと同じ占有帯域幅やサ ービス時間率 (最悪月 $99.7 \%$ ) 維持しつつ，1チャネルあ たり約70Mbpsの伝送容量が確保できる。また，ISDB-Sで 採用されている変調方式に加え，16APSK（16-ary Amplitude and Phase Shift Keying) おょび32APSK (32ary Amplitude and Phase Shift Keying) の導入も検討して おり，16APSK (符号化率3/4) で約93Mbps（受信アンテナ $60 \mathrm{~cm}$ で最悪月サービス時間率 $99.5 \%$ )，32APSK (符号化率 4/5) で, 約 $127 \mathrm{Mbps}$ (受信アンテナ $120 \mathrm{~cm}$ で最悪月サービ ス時間率 $99.5 \%)$ の伝送が可能である.

さらに, 一つのデータストリームを複数のチャネルに分 割して伝送し，受信機で合成することで，大容量のデータ ストリームを伝送するバルク伝送も利用可能となってい る.また, MPEG-2 TSの伝送に加え, 可変長パケットの 伝送も可能である.

(2) 構 成

伝送路符号化の構成を図1に示す，120のスロットからな るフレーム構成を持たせ，スロットを基本として変調方 式・符号化率の指定やTS (ストリーム) IDの指定などの伝 送制御が可能となっている. フレーム化を行った後，デー タおよびTMCC ( Transmission and Multiplexing 
表1 伝送路符号化方式

\begin{tabular}{|c|c|c|}
\hline \multicolumn{2}{|c|}{ 項 目 } & 内 \\
\hline \multicolumn{2}{|c|}{ 変調方式 } & ா/2シフトBPSK, QPSK, 8PSK, 16APSK, 32APSK \\
\hline \multirow[t]{3}{*}{ 誤り訂正方式 } & 内符号 & LDPC(符号長44880) \\
\hline & 符号化率 & $\begin{array}{l}1 / 4(11 / 40), 1 / 3(41 / 120), 2 / 5(49 / 120), 1 / 2(61 / 120), 3 / 5(73 / 120), 2 / 3(27 / 40), 3 / 4(89 / 120), 4 / 5(97 / 120), 5 / 6(101 / 120), \\
7 / 8(7 / 8), 9 / 10(109 / 120) \quad \text { (公称值 (真值) })\end{array}$ \\
\hline & 外符号 & $\mathrm{BCH}(65535,65343, \mathrm{t}=12)$ 短縮符号 \\
\hline \multirow[t]{5}{*}{ 伝送制御信号 } & 変調方式 & $\pi / 2$ シフトBPSK \\
\hline & 内符号 & $\operatorname{LDPC}(31680,9614) ： \operatorname{LDPC}(44880,22814)$ の短縮符号 \\
\hline & 外符号 & $\mathrm{BCH}(9614,9422) ： \operatorname{BCH}(65535,65343)$ の短縮符号 \\
\hline & 制御単位 & スロット単位の伝送制御 \\
\hline & 制御情報 & $\begin{array}{l}\text { ·変調方式拉よび符号化率の制御 ·多重データフォーマット制御（MPEG-2 TS, 可変長パケット） ·階層化伝送制御 } \\
\text { ·緊急警報放送起動制御複 ·数独立TS識別制御 ・バルク伝送 •サイトダイバーシテイ情報 ·衛星中継器動作点設定情報 }\end{array}$ \\
\hline \multicolumn{2}{|c|}{ フレーム構造 } & •120スロット/フレーム ·MPEG-2 TS長の整数倍のスロット長 \\
\hline \multicolumn{2}{|c|}{ シンボルレート } & $32.5941 \mathrm{Mbaud}$ \\
\hline \multicolumn{2}{|l|}{ ロールオフ率 } & 0.1 \\
\hline \multicolumn{2}{|l|}{ その他 } & 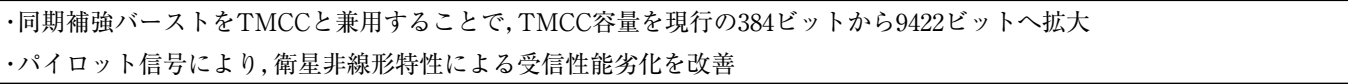 \\
\hline
\end{tabular}

表2 映像符号化方式

\begin{tabular}{|c|c|c|}
\hline 項 & 目 & 内 容 \\
\hline \multicolumn{3}{|l|}{ 映像入カフォーマット } \\
\hline \multirow[t]{3}{*}{ 時空間フォーマット } & 基 本 & $1,920 \times 1,080 / 60 \mathrm{I}, 1,920 \times 1,080 / 60 \mathrm{P}, 3,840 \times 2,160 / 60 \mathrm{P}$ \\
\hline & マルチサービス専用 & $720 \times 480 / 60 \mathrm{I}, 720 \times 480 / 60 \mathrm{P}$ \\
\hline & 実験用 & $7,680 \times 4,320 / 60 \mathrm{P}$ \\
\hline \multirow[t]{3}{*}{ 信号形式 } & & $\mathrm{YCbCr}$ \\
\hline & 輝度·色差信号形式 & 4:2:2(TBD：実証実験により 4:4:4の採否を判断する) \\
\hline & 量子化ビット数 & 8,10 \\
\hline \multirow[t]{5}{*}{ カラリメトリ } & 3原色色度点 & 赤 $(\mathrm{R}) \mathrm{x}: 0.640 \mathrm{y}: 0.330$, 緑 $(\mathrm{G}) \mathrm{x}: 0.300 \mathrm{y}: 0.600$, 青 (B) $\mathrm{x}: 0.150 \mathrm{y}: 0.060(\mathrm{CIE}, 1931)$ \\
\hline & 基準白色 & D65 $\quad \mathrm{x}: 0.3127 \mathrm{y}: 0.3290$ \\
\hline & 光電変換特性 & $\begin{array}{ll}E^{\prime}= \begin{cases}\alpha L^{0.45}-(\alpha-1) & (\beta \leq L) \\
4.50 L & (-\beta<L<\beta) \\
-\alpha(-L)^{0.45}+(\alpha-1) & (L \leq-\beta)\end{cases} & \left\{\begin{array}{l}\alpha \text { および } \beta \text { は, 連立方程式 } \\
4.5 \beta=\alpha \beta^{0.45}-\alpha+1 \text { の解 }\end{array}\right. \\
\text { 8-11ビットの場合, } \alpha=1.099, \beta=0.018 & \end{array}$ \\
\hline & 輝度信号方程式 & $E_{Y}^{\prime}=0.2126 E_{R}^{\prime}+0.7152 E_{G}^{\prime}+0.0722 E_{B}^{\prime}$ \\
\hline & 色差信号方程式 & $E_{C B}^{\prime}=\frac{E_{B}^{\prime}-E_{Y}^{\prime}}{1.8556}=\frac{-0.2126 E_{R}^{\prime}-0.7152 E_{G}^{\prime}+0.9278 E_{B}^{\prime}}{1.8556} \quad E_{C R}^{\prime}=\frac{E_{R}^{\prime}-E_{Y}^{\prime}}{1.5748}=\frac{0.7874 E_{R}^{\prime}-0.7152 E_{G}^{\prime}-0.0722 E_{B}^{\prime}}{1.5748}$ \\
\hline \multicolumn{3}{|l|}{ 映像符号化方式 } \\
\hline \multirow[t]{8}{*}{ 準拠規格 } & & ITU-T H.264 | ISO/IEC 14496-10(MPEG-4 AVC) \\
\hline & プロファイル & High (TBD：実証実験により, High 10, High 4:2:2, High 4:4:4の採否を判断する) \\
\hline & \begin{tabular}{l|l} 
レ & $720 \times 480 / 60 \mathrm{I}$ \\
\cline { 2 - 3 }
\end{tabular} & 3 \\
\hline & ベ $720 \times 480 / 60 \mathrm{P}$ & 3.1 \\
\hline & ル $1,920 \times 1,080 / 60 \mathrm{I}$ & 4 \\
\hline & $1,920 \times 1,080 / 60 \mathrm{P}$ & 4.2 \\
\hline & $3,840 \times 2,160 / 60 \mathrm{P}$ & TBD* \\
\hline & $7,680 \times 4,320 / 60 \mathrm{P}$ & TBD* \\
\hline
\end{tabular}

*ITU-T H.264 | ISO/IEC 14496-10への追加規定が必要

Configuration Control) 信号について，それぞれBCH符号 による符号化，擬似ランダム符号によるエネルギー拡散， およびLDPC符号化が行われる. TMCC用のBCH符号や LDPC符号には, デー夕用と同じ符号を短縮化して利用す ることで, デー夕用の符号化器・復号器を共用できるよう にしている，その後，データについてはTMCCで指定され
た変調方式で，また，TMCC信号については $\pi / 2$ シフト BPSKで変調され，図2の変調信号形式に時分割多重される. 変調信号もまた，フレーム構成を持っており，120の変調 スロットで構成される，各変調スロットには，24シンボル の同期シンボル，32シンボルのパイロットシンボルに続き, 136シンボルのデータシンボルと, 4シンボルのTMCCシン 
表3 音声符号化方式

\begin{tabular}{|c|c|}
\hline 項 目 & 内 容 \\
\hline \multicolumn{2}{|l|}{ 音声入力信号 } \\
\hline 最大入力音声チャネル数 & 22.2チャネル（1ストリームあたり） \\
\hline 量子化ビット数 & $16,20,24$ ビット \\
\hline 音声モード & $\begin{array}{l}\text { モノラル, ステレオ,2音声(デュアルモノラル), マルチチャネルステレオ } \\
(0-3 / 0 / 0-0.0(3.0), 0-2 / 0 / 1-0.0(3.0), 0-3 / 0 / 1-0.0(4.0), 0-2 / 0 / 2-0.0(4.0), \underline{0-3 / 0 / 2-0.0(5.0)}, 0-3 / 0 / 2-0.1(5.1), 0-3 / 0 / 3-0.1(6.1) \\
\text { 2/0/0-2/0/2-0.1 (6.1), } \underline{0-5 / 0 / 2-0.1(7.1)}, \underline{0-3 / 2 / 2-0.1(7.1)}, \underline{2 / 0 / 0-3 / 0 / 2-0.1(7.1)}, 0 / 2 / 0-3 / 0 / 2-0.1(7.1), 2 / 0 / 0-3 / 2 / 3-0.2(10.2), \\
3 / 3 / 3-5 / 2 / 3-3 / 0 / 0.2(22.2)) * \text { 《下線を引いたモードが推奨音声モード》 }\end{array}$ \\
\hline \multicolumn{2}{|c|}{ 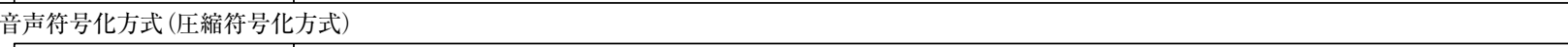 } \\
\hline 符号化方式 & MPEG-2 AAC LCプロファイル ※AAC+SBR (Spectral Band Replication)の使用も可能 \\
\hline 符号化パラメータ & 既存方式に順ずる ※ただし, 音声入力信号の拡張に伴うパラメータの拡張を実施 \\
\hline \multicolumn{2}{|c|}{ 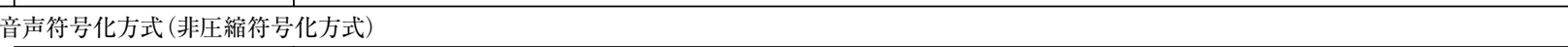 } \\
\hline 符号化方式·伝送方式 & リニアPCM音声符号化 \\
\hline 最大音声入力チャネル数 & 5.1 チャネル \\
\hline
\end{tabular}

*マルチチャネルステレオの音声モード表記法として, チャネル数を上層一中層一下層.LFE次のように表す.

割当てチャネルがない層は 0 とし, 割当てチャネルがある層のチャネル数をフロントハミドルリアのように表す. 括弧内は従来の表記.

表4 多重化方式

\begin{tabular}{|c|c|c|}
\hline \multicolumn{2}{|r|}{ 項 目 } & 内 \\
\hline \multicolumn{2}{|c|}{ リアルタイム型放送 多重化方式 } & ITU-T H.222.0'ISO/IEC 138181-1 (MPEG-2 Systems) \\
\hline \multirow{2}{*}{\multicolumn{2}{|c|}{\begin{tabular}{|l|} 
PESパケット, セクション形式 \\
TSパケット, 伝送制御信号, 識別子
\end{tabular}}} & 平成15年総務省令第26号 (一部改正:平成19年総務省令第25号) 1章第3条 \\
\hline & & 平成15年総務省告示第37号 (一部改正:平成16年総務省告示第726号および平成19年総務省告示第133号) \\
\hline & 衛星分配システム記述子 & 変調方式抒よびFEC(内符号)の識別領域に「高度衛星デジタル放送方式」を追加 \\
\hline & システム管理記述子 & $\begin{array}{l}\text { 放送の標準方式の種別と割当てに「高度衛星デジタル放送方式 (11.7〜 12.2GHzの周波数において34.5MHz帯域幅)」 } \\
\text { 拉よび「高度衛星デジタル放送方式 (12.2 12.75GHzの周波数に执いて } 34.5 \mathrm{MHz} \text { 帯域幅)」を追加 }\end{array}$ \\
\hline \multicolumn{2}{|c|}{ 蓄積型放送サービス 新多重化方式 } & TLV (Type Length Value) 多重化方式 \\
\hline \multirow[t]{2}{*}{ TLV } & 特 徵 & $\begin{array}{l}\text { 可変長で長パケットでの伝送が可能 } \\
\text { ·packet_type(パケット種別) フィールドによりデータの種類を示し, length (データ長) フィールドによりデータの } \\
\text { 長さを示すことで, 任意の可変長データを格納可能 }\end{array}$ \\
\hline & 格納する可変長パケット種別 & $\mathrm{IPv} 4$ パケット, IPv6 パケット,ヘッダ圧縮IP パケット, ヌルパケット \\
\hline \multicolumn{2}{|c|}{ IPパケットのヘッダ圧縮方式 } & $\begin{array}{l}\text { IPパケット化されたコンテンツをTLVに多重する場合, ほぼ同一内容のヘッダを持つパケットが連続するため, IP } \\
\text { パケットのヘッダを压縮することによって伝送オーバヘッドを削減.すべてのパケットのヘッダ情報をすべて伝送 } \\
\text { する代わりに,フルヘッダのパケットを間欠的に伝送し,他のパケットでは圧縮へッダに付け替えて伝送し受信側 } \\
\text { でヘッダ情報を復元. }\end{array}$ \\
\hline
\end{tabular}

表5 データ符号化・伝送方式

\begin{tabular}{|c|c|}
\hline 項 目 & 容 \\
\hline ت゙ー夕符号化, 伝送方式 & " ARIB-J (ARIB STD-B23) によるデー夕符号化, 伝送 \\
\hline \multirow[t]{7}{*}{ 機能拡張 } & (1)アプリケーション蓄積 \\
\hline & ·Javaクラスライブラリーの受信機への蓄積, 実行, 管理機能の追加 \\
\hline & (2) ディジタルビデオレコーダ制御 \\
\hline & •録画, 再生, トリックプレイ, 予約等に関するAPIの追加 \\
\hline & (3) 宅内ネットワークアクセス機能 \\
\hline & •アプリケーションからUPnP拉よびUPnP AVを利用するためのAPIの追加, Digital Media Server機能の追加等 \\
\hline & $\begin{array}{l}\text { (4) ユーザインタフェース拡張 } \\
\text { •ディスプレイサイズや解像度など受信機特性の保持およびアプリケーションからの参照機能の追加, 受信機特性に応じた提示 } \\
\text { のためのユーザインタフェースコンボーネントおよびマルチメディアコンテンツ記述法の追加 }\end{array}$ \\
\hline
\end{tabular}

ボルが交互に66回多重される.

パイロットシンボルでは, デー夕伝送に用いられる変調 方式・符号化率に対応する信号点を既知の順序で繰り返し

$684 \quad(52)$
伝送する．受信機側でこれを同じ信号点ごとに平均化する ことで, 衛星中継器の非線形の影響を受けた後の信号点配 置がわかるので最適なLDPC復号が可能となる. 


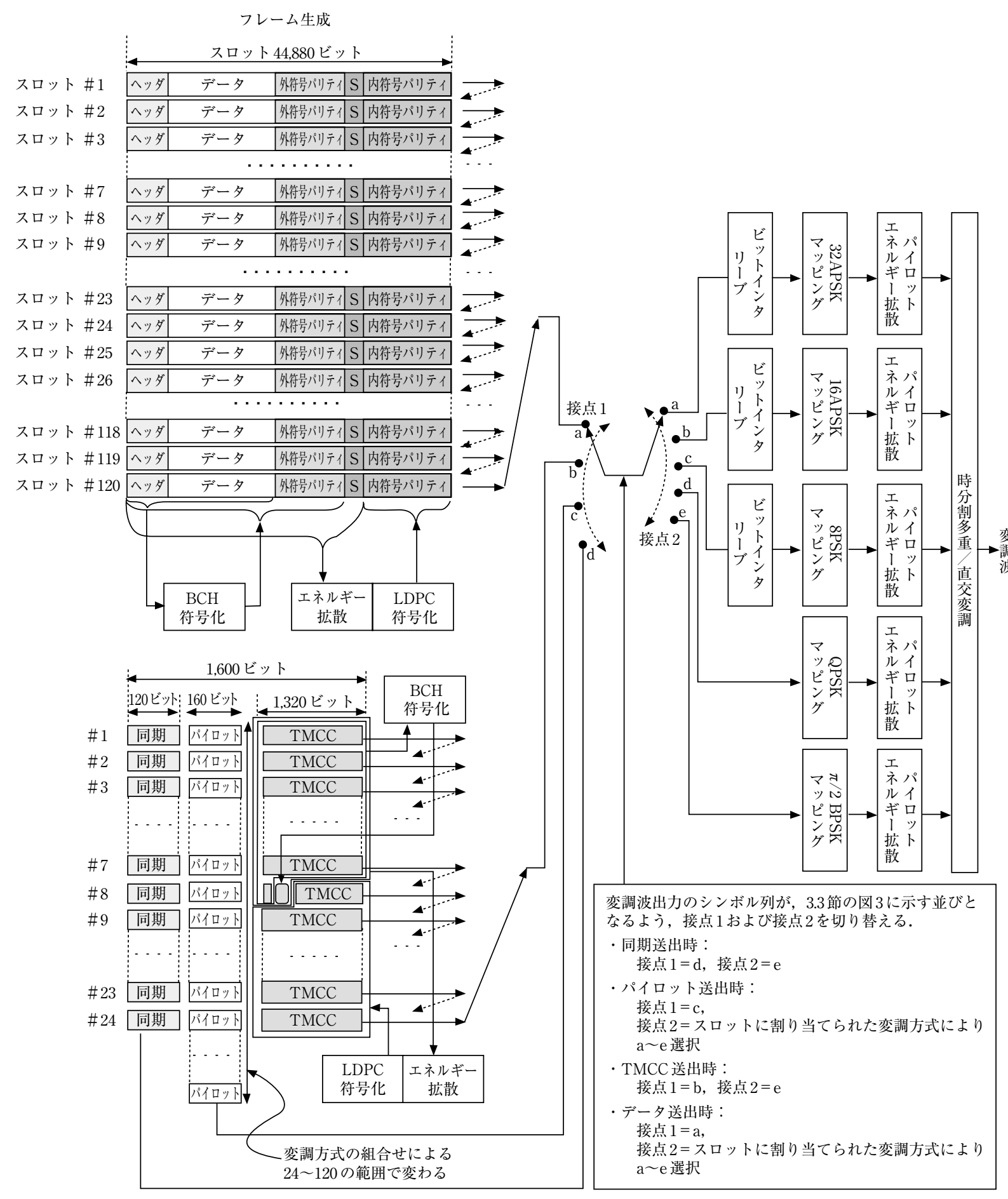

図 1 伝送路符号化

また，キャリヤ再生補強用の位相基準バースト信号を利 用してTMCC信号を送ることで，効率低下なしにTMCCの 情報容量を拡大し，高機能化を図っている.

\section{2 映像符号化方式}

映像入力フォーマットについては，現行BSの $1,920 \times$ 1,080/60Iとともに $1,920 \times 1,080 / 60 \mathrm{P}, 3,840 \times 2,160 / 60 \mathrm{P}$, $7,680 \times 4,320 / 60 \mathrm{P}$ (実験用) を採用し，また，負RGB方式に
よる色域拡大方式を含む内容となっているままた，映像符 号化方式については, MPEG-4 AVC (ITU-T H.264| ISO/IEC 14496-10）を採用している.

\section{3 音声符号化方式}

音声入力フォーマットについては，22チャネルと低域強 調用 2 チャネルからなる 22.2 マルチチャネル音響信号を最大 入力音声チャネルとしている. 


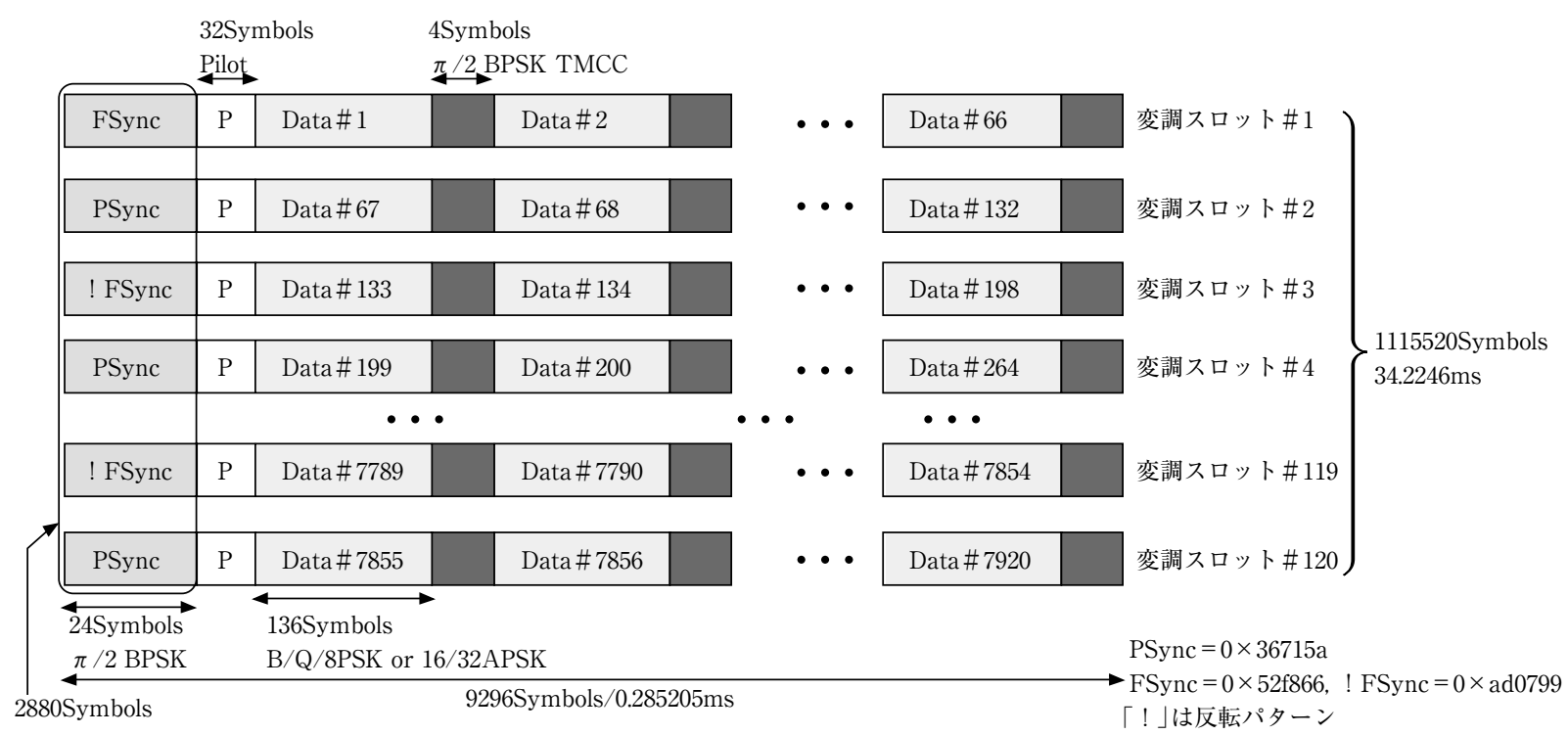

図2 变調信号形式

音声符号化方式については，現行のMPEG-2 AACに加え てSBRの使用も可能とし，また，非圧縮リニアPCM (最大 5.1 チャネル）も可能としている.

\section{4 多重化方式}

現行のMPEG-2 Systemsに基づく方式に加えて, 蓄積型 放送サービスのために, IPパケット等可変長パケットの伝 送を可能とする多重化方式を採用している.

\section{5 データ放送方式}

現在実施されているXMLベースのデータ放送方式を超え る表現能力や, データ放送サービスの一層の柔軟性や拡張 性を確保するため, Javaベースのデータ放送方式を採用し ている。具体的には, ARIB STD-B23 (ARIB-J)を基本と し，端末の特性に応じた提示や宅内ネットワークアクセス 機能, 放送コンテンツの蓄積機能の追加を行っている.

\section{6 限定受信方式}

限定受信方式については, 現行のARIB STD-B25（限定 受信方式)の採用継続を基本としている.

\section{4 今後の展開}

本年後半には情通審から諮問2023号に対する一部答申と して, 衛星デジタル放送の高度化方式として本方式が
ARIB実験結果とともに報告される見通しである。その後, ARIBにおいて関係規格の整備が予定されている.

\section{5 むす び}

本稿では, 現在ARIBで審議中の高度BSデジタル放送の 暫定方式案について解説した.

なお，最終的な規格については，中間報告以降の審議に より，本稿の内容が修正される可能性がある.

(2008年2月28日受付)

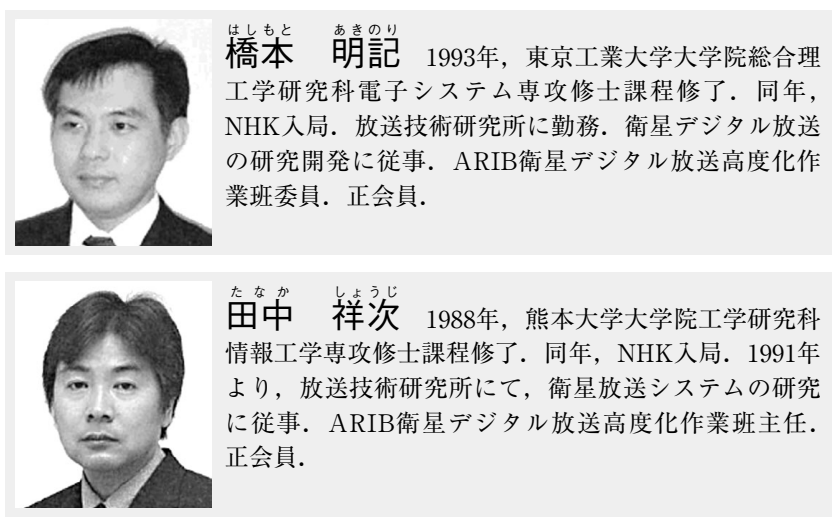

